\title{
Iranian Electoral Politics in 21st Century and its Consequences on National Growth
}

\author{
Syed Raheem Abbas ${ }^{a}$ and Muhammad Asim ${ }^{\text {b* }}$ \\ ${ }^{a}$ College Bhakkar \\ Pakistan \\ ${ }^{b}$ College Asghar Mall, Rawalpindi \\ Pakistan
}

Received 18.02.2015, received in revised form 21.03.2015, accepted 07.04.2015

After the revolution of 1979, Iran political system was converted into presidential type of government within the theocratic structure. That was totally a new experience for the people of Iran after Pehlavi Dynasty. But, this system proof as successful governing system that facilitated national growth as well. This article highlights Iranian electoral politics and points out the results of presidential elections in 21st century. Policies announced by the presidents are also discussed here. And, the consequences of these policies on national growth are also presented in the last of this article.

Keywords: Pehlavi, Khatimi, Ahmadi Nizad, SAT, Khamnai.

Research area: politology.

\section{Hypothesis}

Although Iranian electoral politics is faced so many controversies but its consequences on national growth are prove of its successful governing structure even under the theocratic elite.

\section{Research Methodology}

This research is based on historical descriptive, analytical, comparative and qualitative methods. The data is collected from books, research journals, news papers, internet, interviews, results of different dissertations, and personal visit of Iran in which attending several seminars, workshops and training classes including visiting several universities and Research Centers in Qom and Tehran.

\section{Introduction}

The masses in the democratic Iran have been completely satisfied with the system of government as well as the strength of democracy in the republic .The all-round progress and prosperity in the country has developed a healthy sound and positive public opinion.All the witness go in the favor of the democratic development and I have discussed them in detail as per tenure and period of each government please have a glance of it.

(C) Siberian Federal University. All rights reserved

* Corresponding author E-mail address: raheemabbas786@gmail.com, asimsheikh62@yahoo.com 


\section{Presidential Election 2001}

The election of 2001 held on 8 June 2001 ,in these election voter turnout remained almost $68 \%$. Candidates remained successful to stand in the election out of these 10 Syed Muhammad Khatami again carried the day.

\section{Syed Muhammad Khatimi and its Policies (1997-2005)}

In 1997 public of Iran selected Khatami as the $5^{\text {th }}$ president of Iran by casting $70 \%$ votes in his favor. He gave his party statement different for the rest. Patience has freedom of thinking, obedience of rules and regulations. These slogans got importance not only in public but also in scholars at world level he instead of clash of civilization and religious preferred the dialogue among them his theory got so much importance that UNO celebrated the dialogue among civilization in the year 2001. He gave new life in politics and as results in 2001 he was again selected as president for next four years.

He has deeply studied the politics of west and reaches on this conclusion that politics of world has propaganda and it's double faced. (Kesselman, 2013, p. 342)

\section{Presidential Election 2005}

In 2005 again enhancing democratic power for election were organized and conducted at proper time this time round of election were done for the first time in the history of Iran .in first timer time no political party got the desired majority and hence round two was organized ,as a result of which Ahmadi Nizad became the president of Iran. He was the first president of Iran who was not among the clerics. He has great vision for social problem .He travelled all over the Iran and gave relief to the former and poor people, because he himself belonged to middle class family. (http://iranelectionwatch.com/pastresults/, 2009, p. 04)
In first round no candidate could get the desired majority so second round of the election was organized on June 24, 2005. In these election voter turnout remains $60 \%$ and according to the constitution this election was between the two topper that is the winner of the first round and first runner up, after the result of the second round Muhammad Ahmadi Nizad former of Mayer of Tehran became the president of Iran.

\section{Presidential Election 2009}

After the successful completion of 4 years again general president election conducted on 12 June 2009.in these election people heavily participated and cast their votes in a great number. (Steinfeld, 4th july 2009, p. 09)

The number of casted vote was record in history of Iran, voter turnout remained $85 \%$.in all these election only four (4) candidates remained fortunate to stand and run the race president ship while 471 candidates dropped due to strict scrutiny process by the Guardian Council in these election Muhammad Ahmadi Nizad remained victorious by a great margin of almost $30 \%$ votes. (Horris, 2013, p. 09)

\section{Ahmadi Nizad as A President of Iran}

On June 2005 after the declaration of result of election next day the supporters of Ahmadi Nizad were quite excited because their representative has got 1 crore 15 lac votes and his opponent got 1 crore votes. In this way Ahmadi got 65.69 votes and Rafsanjani got 35.9 votes. After clear cut success the speech which he delivered was wonderful that was reflection of his generosity and cooperation. He said in a powerful take that we have built an ideal society and programmed Islamic society from Today all enmities should change into friendliness. We are also the members of large families. We should make Iran successful by joining hands with hands. 
By this speech Rafsanjani terrified the people that here will be anarchy in the country Rafsanjani has no more courage to fight so he left all the matter on Allah and considered silence better in this matter. (Addis, July 2009, pp. 1-15)

\section{Ahmadi Nizad First Region of Presidency}

Ahmadi Nizad as a president has done most of work according to the wishes of public and in this matter he never cared for the budget and for the service of public he established a fund name Imam Raze love fund By this fund youth are helped during their marriage. By this youth got excited because the youngsters are not only helped in marriage but they also get financial help for employment and house from this "Imam Raza (a.s) Love fund "Increase in the pay of nurses.

The pay of nurses was much less as compare to their work. That's why Ahmadi Nizad increased pays as and together facilities about $30 \%$ and with this he also announced the increase in the pension of retired people. In this way in his former years of presidency .He spent 78.30 Arab dollars for the welfare of public within the two years of his earlier presidency he has visited all the 30 provinces of his country. He addressed in 2000 small cities to gathering. And the promise of financial help by the government has also become a cause to increase the people of gathering. And needy people came there with this hope that they will surely get some sort of help. And in this net cash help 40 dollars was fixed. And for much needy people 200 dollars were fixed. And for serious patients and university students there was also help package.

By these visits there created a relation of president and public, and before this politician had never given attention to this poor people of the society. By the visits of far sighted areas of Iran enabled Ahmadinejad to proclaim that he is a public president and will solve their problem by going to their homes. And he got fame as an ideal president that he contacts with his public all the time. That he had given a dream of better future to his public and he had he had faced the worlds comradely before this Dr. Mundaq Araned as Ahmadi Nizad arranged as a public leader and Ahmadi Nizad could preen homely as a public leader. (Ghzain, feb 2012, pp. 1-7)

Not only in Iran but in Arab world and Islamic world he has got the status of Muslim leader some considered him leader of these greet leader and the individuals of Islamic world respected him because he was such a leader who had faced the written lobby so bravely.

\section{Justification of Protector Council}

Protector council (shura e Nighaban) has also rejected the allegations of corruption in the election campaign perfectly and certified the success of Ahmadi Nizad as the president of Islamic republic of Iran. G-8 countries told that there is a chance of restrictions on Iran by the world. According to media after the counting of votes of presidency election the leader of shura e Nighaban (protector council) has given the decision. According to that decision it is said in a letter send to Iranian defense ministry that during the election campaign all the mirror illegalities don't come under corruption and it's of minor types. The leader of Supreme Court of Iran Ayatullah Khamnai and guardian council has declared that election was clear and perfect.

\section{Justification / Certification of Khamanai}

The great spiritual leader of Iran Ayatullah Khamnai has also certified the Ahamdi Nizad as the president of Iran. According to government T.V the spiritual leader has $2^{\text {nd }}$ time appointed Ahmad Nizad as the president of Iran and further said about this that the selection of Ahmadi Nizad is clear reflection of Public struggle for justice. Iranian public has voted against the oppression 
and on the other side the opposition leader Mir Muhammad Hussain has not participated in this election. Ahmad Nizad again has taken the oath of this post on 15 August and argued that the boycotts after presidency election are the result of external interferences. Every country should avoid indulging in the internal matters of Iran. (Rights, 2009, p. 55)

\section{Cause of Success of Ahmadi Nizad}

Ahmadi Nizad presented himself as public leader. He did not spend a single penny on his election campaign during his complain he did not leave any area to whom he has not visited. Opposite to Ahmadi Nizad, Rafsanjani and others belonged to elite class, but the Ahmadi Nizad belonged a poor section of a society that's why the poor public votes him in majority.

\section{Fear of Extend World}

Now only the Iranian reformers were wonder stricken on these results but also for the outer powers results were astonishing.

However the British People showed a special behavior .In a very conscious way exterior ministry of America gave very strict address that America is still doubtful about the Iran that where it fulfills the demands of his nation or removes the fear of international community. America never looks at Ahamd Nizad as the friend of America that was the reason America has much supported the opposition's allegations of corruption in election on media.

Mahmoud Ahmadi Nizad had been selected as a president by winning the election $2^{\text {nd }}$ time. Before this he defeated in election the pervious Rafsanjani. In this competition he fails of getting $50 \%$ votes. Ahmadi Nizad appeared accidentally and wonderfully in front of scene and Nataq Noori remained on $3^{\text {rd }}$ No According to world media Iranian were not so much excited in presidency election before and during the $2^{\text {nd }}$ tenure the
Supreme Leader (Rehbar-e-Muazam) of Iran has considered the success of Ahamdi Nizad a slap on the face of America and said that Iranian public had shown his hidden power against the world polices. Mahmoud Ahmadi Nizad said he will make Iran a new and powerful country which can become entangle for others. The relations with America is the not the solution of our problems. (Mahmood, 2006, p. 91)

Before the president Khatami, Iran was following the steps of Imam Khumaini. The tenure of Imam Khumaini and Khamnai paned in such a way that America has not a courage to disturb Iran but after this Hashim Ali Rafsanjani and after this Muhammad Khatami on the names of reforms had taken a lot of matters from the revaluations. During their tenure it was widely and openly said that Iran is opening the door for the western world and Iran is becoming much more Liberal. But now again western media had said that now, Iran is again to the dark ways. Primitivism after heading the new of Ahmadi success they raised voice that there is corruption in election but their voices were so much low that at last Rafsanjani accepted the defeat.

Rafsanjani during his both presidency tenures has tried to set his relation with America and continued the reforms also and this process continued till the age of Khatami as the news of Ahmadi Nizad's is success prevailed the western media propagated that not only the doors of reforms were closed in Iran but also the Iran is totally covered with old theocracy America at once said that our views about Iran will never change. (Iran U. o., 2009, p. 18)

Ahmadi Nizad after 1981 was the first president who was not a religious scholar. $\mathrm{He}$ promised that his government will be a just govt.

Ahmadi Nizad is quite famous for his steps that he has taken about corruption. It is written on his website that "America and west will allow 
the progress of Iran but we will never bow before their will".

Ahmadi Nizad was quite famous for his simple life style. He stayed in his own house and neither had he used the govt. conveyance and he used his old car. During this he removed the fast food restaurant based on western style, and he ordered long sleeves shirts for workers and wearing of beard necessary for them.

Before the Ahmadi Nizad both the presidents have not fulfilled the hopes of public Hashim never considered it necessary to have relation will public and have never visited the public out of them. Khatami said good bye to simple living and put resident in palace, which is disliked by the public after both them when Ahmadi Nizad came forwarded public got a public leader whose they consider their savor and voted him excitedly.

America according to his own plan was dreaming about a greatest Middle East, and it started from Afghanistan and Iraq, but Iran despite the threats and dangers remained firm before him. Iran is proud of Muslim world for the bravery with which he has forced the America and Israel and its important success is that Iran bitterly hurtled or teased America in the world politically and in outer world relations. To his cold war with America Ahmadi Nizad has become the revolutionary leader of Middle East. In the area due to his policies anti-American views got support or favour and people considered him savior. Every saying of Ahmadi Nizad against America and went has given him glamorize popularity. Now he is raising not only the leader of Iran but also of whole Muslim Ummah. Sometimes he wonders the Israel by his say the holocaust and sometime he becomes center of attention after writing letter to American president. (Hiyyat, 2009, p.117)

Hiyyat says that, on one side he has still continued the argumentation on atomic program and on the other side he is the working on the nuclear reactor is much raped. Iran has now become self-strong from defense point of view, to such an extent that Israel is now at the target of his missiles. Israel which can't be defeated by any Islamic country in Lebanon and Gaza due to the support of Iran Israel has got bitter failure Iran has fought outside his own country and proved that he can fight against the weapons of America and Israel. (Hiyyat, 2009, p. 119)

In this way Ahmdi Nizad not only gave confindence to the iran nation but he also guided them positivly toword progress.

Iranian revolution made a great history and it became an example for other countries of the world, it gave many benefits to the Iranian nation besides the growth of self-confidence dignity and other moral values, Iran also excelled in every walk of life. Iran made rapid promotion in education, science and technology, atom energy, agriculture, heavy industry, communication, and so on. The detail of all these are given below.

\section{National Growth in $21^{\text {st }}$ Century}

Let's have a look at the progress and development offered by democratic political System of to Iran.

\section{Education}

Iran ranks first in the dissemination of religious Islamic books, and is the world's fourth country in which libraries are working round the clock. Depending on the number of libraries Iran is in top fifteen countries. There are more than 1, 24,000 school donors in Iran. Iran ranks first regarding distribution of milk among the students by school. Iran's first satellite designed by the students is almost ready. Iran is one of top fifteen countries providing higher education environment. Number of Articles by Jihad Ilmi Danshigahi has exceeded 61 thousand. SAT positioned Iran in the first place for the distance education system in the world. Iran ranks first in 
the world with the higher proportion of number of students.

After the blessed Islamic Revolution in Iran, more than 200 Encyclopedias have been published. The impact of scientific journals and broadcasting of Iran is on highest index level. Iran in the field of chemistry has received considerable targets. Number of articles related to nuclear issues in Iran is hundred times bigger than the rest of world. Iranian Electronic Education Department is ranked first in the Middle East. Iran's development of nuclear science is more than $80 \%$ as compared with the rest of world .The number of students in colleges and universities in Iran is $20 \%$ more than that of before the blessed revolution. More than $25 \%$ of the articles on Sociology were written by Iran in the world. (Ali, 2013)

\section{Agriculture}

Iran is self-sufficient in wheat production, and ranks eighth in the world in the production of honey. $96 \%$ saffron is produced in Iran. Iran is the world's third largest country in walnut production and the world's third largest country in the production of peanuts. Iran self-sufficient in the production of potatoes seed. Iran is one of four countries producing hybrid rice technology. Depending on the extent of land under wheat cultivation, Iran is second in the world. Nine types of Iranian fruits ranks from first to third in the world. Agricultural commodity production has quadrupled since the Islamic Revolution. Iran in the production of milk and related products is in fifth place in Asia. Iran is the world's second largest country in date production. Iran's $90 \%$ self-sufficiency makes her most peaceful country in the world. (UNIDO, 2003, p. 101)

\section{Health}

Iran is third biggest country in the world to produce cold temperature injections, and ended monopoly in the production of bioimplant. Iran succeeded in patching red blood cells. Iran ended Britich/American monopoly by producing Botulinum Toxin. $95 \%$ of the drugs being consumed in the country are produced in Iran. Regarding preparation of Medical Sciences articles, Iran is in top countries in the world. Iran for the very first time in the world has successfully created wave distributor hear vein assistant. Regarding infertility treatment facilities Iran holds place in the world's top ten countries. The world's first time machine to weigh the newborn is accompanied by bronco beater Iran has developed In number of voluntarily blood donors, Iran has higher level as compared with other regional countries. (Ali, 2013, p. 56)

By patching cells using radio medicines, Iran ended American monopoly. Iran holds first position in regional countries in the treatment of Hepatitis. Iran ended thirteen years old American monopoly by launching anti-cancer medicine in the market. Using of nuclear technology, the radio Medicine is made locally in Iran. In reducing deaths of pregnant domestic women, Iran is among the top three countries of the world. Iran is third largest country in preparation of hearing snails. In brain and nerve surgery, Iran is ranked first in regional countries. Iran, in mad dog bite disease (rabies) prevention, is in first place. Iran's Plastic surgery is considered world's auto advance top level countries. The process of getting children vaccinated in Iran is 95 percent completed in their childhood. In safety equipment production and exports Iran has become self-sufficient. Lung surgery, Iran is ranked first in regional countries. Iran in the field of orthopedic is one of the world's first ten countries. Medical equipment, resources, and products, Iran leads regional countries. For the first time in the world, in Iran, artificial cornia has been developed for those suffering eye cornia. 


\section{Gas and oil}

Iran has become the club member of countries exporting aircraft petrol, and is in top level countries of Asia, in development of $\mathrm{CNG}$ industry. Iranian National Oil Company has been recognized as the world's second largest company. (IIias, 2009, p. 12)

Iran has achieved catalyst technology being used in oil products, and has gained crude oil desalination technology. In petrochemical products, Iran is world's second largest country. Iran has acquired computerized and modern technology in drilling oil and gas. Iran has joined the countries converting liquefied petroleum gas. (Habibi, 2011)

\section{Communication}

In terms of the number of branches of post offices Iran is ranked eighth in the world. The first optical fiber has been developed in Iran. In number of mobile phone subscribers in the world, Iran is ranked twenty-fourth. Islamic Revolutionary Syed Ali Khamnai's website is mostly visited in the Middle East. Iran in terms of the number of internet pages in the world has thirty-second numbers. Iran is to create the greatest arch bridge in the Middle East. (http://www.mangabuy.com, 2006, p. 09)

\section{Public welfare}

In world relief and support Iran is in first ten countries in the world. The highest number of refugees of the world is in Iran. (UNIDO, 2003, p. 37)

\section{Defense system of Iran}

Iran has developed anti-missile radar system (disturbing missile radar system).Iran's has successfully test-fired "Noor" surface to surface missile. Iran has successfully test-fired "Mehrab" a ground to air invisible to radar missile. The Iran has developed magnetic steel shell weapons. Iran is making cruise missiles at large levels. On the pattern of the S-300, Iran has developed air defense systems. The power of "Saiqa" Iranian Jet fighter is more than that of the fourth generation of aircraft, helicopter specialists are ranked fourth in the world. Iran exports military equipment to eighteen countries in the world. Iran is self-sufficient in the production of missiles. (http://www. induxmundi.com/iran/economy, 2013, p. 05)

Iranian anti-tank rocket at $1300 \mathrm{M}$ range are being produced in large numbers, and has test-fired inter-continental ballistic missile successfully. Iran has developed and tested $1100 \mathrm{KM}$ range radar and has developed underground missile cells. Iran has developed without fuel aircrafts. Iran has begun production of third-generation bomb. Iran has acquired anti-cruise missile technology. (Ali, 2013, p. 57)

\section{Development of Technology}

Biological Technology in Iran, in regional countries ranks first and in world ranks fourteenth .Has succeeded in first phase of developing atomic fuel from natural uranium. Iran is self-sufficient in the production of mono colonel bodies' and first time nano-machismlypyzm-machine developing technology. Iran has developed unmanned solar aircraft .Iran in Middle East, in CD and DVD production is largest country. Iran is the world's fastest country with the 11 times more progress in the field of science. (UNIDO, 2003, p. 44)

Production of educational software by Iran in the Middle East is the largest. Eleven times fast development in science that the world, makes Iran first in regional countries and $11^{\text {th }}$ in the world ranking. Regarding stem cells related articles; Iran is at number four in the world. Regarding ecology and environment in July 2013 Iran was the most respected country in the world. Congenital blindness genes were discovered in Iran. Iran in supercomputer making technology is ranked 
tenth in the world of technology. Iran is one of eight countries launching satellite in space. Iran becomes on the world's 25 countries with nuclear fuel. Iran has the world's third country to have the vertical string tunnel. Iran has developed hybrid tractor models.

Using remains of date, Iran succeeded in producing industrial Ethanol and in steel production is on number 15 in the world. As a result of the imposition of sanctions by the UN, the banned imported equipment making industry has been set up in Tabriz. Iran has acquired copper powder nan-technology. The first industrial design of Iranian solar electric motor (sterling trucks) has been developed. Iran is self-sufficient in making steel sheets used in the aircraft industry products. Iranian experts have created the biggest marine diversity system in the Middle East. Iranian company to build biggest gas turbine is on the number six in the world. Iran is now listed in countries making "duel fuel engines" diesel engines. Iran is skilled in the making metro trains. Iran has successfully used crackers of Magenez and Chlorine. Iran ranks eleventh in the world, in car production. Iran has become self-sufficient in creating drilling towers. Iranian-made tractors are being used all over the world.

"Sorna", a human-like robot, by Iran, is now one of the world's five major robots. Iranian expert invented a machine for surgery on insects. After the Islamic revolution in Iran's domestic production has increased 7 times. In making equipment and resources in the oil fields of Iran is self-sufficient. Iran has acquired technology for deep sea drilling. Iran to convert gas to liquid is one of three countries in the world. Iran ended American monopoly in technology of measuring, drilling Oil and creating resources. Iran has acquired 80 mega pixel telescope technologies. By controlling down RA 70 US drone, Iran has showed her power and technology. Iran acquired unmanned flying craft technology. Iran by making satellite is one of eight countries in the world. Iran has acquired technology to build submarines. Iran is one of nine Carbon fiber making countries.

Iran is one of 10 countries with complete space technology. Iran carrying the higherrange electro-optical Systems has acquired technology. Iran has developed plane with ability to fly vertically. The model of multipurpose aircraft and helicopter motor is made in Iran. Tunnel-making ability of Iran has increased 11 times. Iran is one of the ten best countries with powerful skills and engineers to build roads.

Iran has created drifting war model. Iran has created for the first time road side alarm system. Iran is a country with advanced technology in digital conversion. In high radio frequency Iran has successfully created the radio telescope and has acquired technology to convert clouds into Rain clouds. Iran for the very first time has successfully created dry Aluminum Oxide. (Ali, 2013, p. 58)

\section{Environment}

Half of the total heroin smuggled was seized in Iran. Iran is the seventh country in the world with meteorological information centers (Maloney, 2011, p. 11)

\section{Industry\& Commerce production of Iran}

Iranian steel production has grown $31 \%$. Iran's cement industry has largest capacity in the Middle East. Iran is fifth largest country with handicraft and Ceramics production. "Dna" latest modern car has been launched by Iran. "Iran Khodro", a car making company, is one of the largest 16 car making companies.

Iran has developed Direct Oil Heater Furnace. Iran is working over "Leo" the most 
modern television network. Iran is a country exporting secrete sheet. Iran is third in dam building. Iran has joined countries with skill to developed peroxide. Iran has become selfsufficient in marine industry. Iran has ended American monopoly by manufacturing high pressure industrial oil and gas pumps. Iranian carpet is the best carpet in the world. Iran is third handicrafts. In ship making industry, Iran is the top 20 developed countries. (UNIDO, 2003, p. 44)

\section{Sport and Culture position of Iran in the world}

Iran, in the Middle East's is the largest center for computer games and is on number four, in making films on domestic issues. Iran is on number 13 in making films. Iran is one of ten countries achieving student Olympic medals. Iran's volleyball team is among the world's 12 best teams. Iranian football team is on number 1 in Asia and on number 6 in world. Iranian karate team is ranked $8^{\text {th }}$ in the world. Iranian Body builder's team holds championship title. Iranian women's team took first place in Kung Fu. Iranian wrestling team has been world champion. Iran's shooting team has been on top in Asia. Iranian karate team won second place in the world. Regarding Insurance for women Iran is on number one in the world. In introducing insurance plans Iran is on number 3 in Middle East. Iranian guarantee system is on number 1 in this region. Iran is one of the six countries with external transit system. (http://www.mangabuy. com, 2006, p. 07)

\section{Transport}

Iran to continue the process of dry port is ranked twenty-fourth in the world. Iranian marines broke the German record of Ha Sho by diving in sea for 66 days. The biggest title of ship sailing went to Iran's National Oil Company. The third ship to cross ocean Atlantic has been set on sails.

\section{Finance}

Iran is ranked third in the world in Poultry Production. Tehran stock exchange market in 2011 was the world's fastest. In installation of ATM Iran is in second place in the Middle East and Africa. Iran is on top in investment in Islamic banking with the biggest foreign exchange reserves Iran is on number eight in the world. Iran took fourth position in foreign investment. In transit economics Iran is on number 2 in this region. Iran has been considered as a center of development in the Middle East.

World has recognized Iran as $19^{\text {th }}$ economic power. Iran is on number 4, to build underground train (metro). In Middle East Iran is a country with the largest ships. Iran in transportation of grains is the most developed and four times greater than the rest of world. After the revolution, in highway construction, progress ratio has been 3500 percent. Iran is largest ship maker in the Middle East. (Ali, 2013)

\section{Materials production of Iran}

Iran is with the world's top mining countries. Iran is the third largest country, with mineral stones .Iran is one the highest copper producing country. Iran is has acquired technology in creating aluminum alloy.

\section{Livestock position}

Iran is on number ten in egg production, and is in top shrimp producing countries in the Middle East. Iranian researchers have been successful in high yielding fish in dry areas. Iran with 1130 types of animals is on top. (UNIDO, 2003, p. 115)

At the end of this discussion I shall say that the continuity of election process after 
revolution tell us that democracy is going on its way smoothly in Iran. It is quite clear from all the facts and fingers those elections of all types weather they are presidential, Majlis-e-Shoora, or local bodies' are being held after proper time. In all election after revolution it is clear from the discussion that every party made its goals for the progress of the country and very truly when any party comes in power its tries to fulfill most the promises that they have done with the people
So major principle of democracy which are real beauty of democracy are also the ingredients of Iranian democracy.

Iranian electoral politics is always criticized by the west but it is always appreciated by the people of Iran who participate in electoral system with the happy heart. This is the result that National Growth of Iran is reaching at top three levels in all over the Middle East and Third World countries.

\section{References}

1. Ali, R. M. (2013). Peggam e Assana Sumara No 46(Urud). Islamabad: Culture Councilat Islamic Republic of Iran.

2. Ghzain, H. (feb 2012). The ninth Parliamentray Election in ran. International Scholer , 1-7.

3. Ghzain, H. (feb 2012). The ninth Parliamentray Election in ran. International Scholer , 1-7.

4. http://www.induxmundi.com/iran/economy. (2013). Iran Economy Profial 2013. 05.

5. http://www.mangabuy.com. (2006). The Economy of Iran. 09

6. Iran, U. o. (2009). Jerrold D Green. Rand, Congress Liberary, 24.

7. Kesselman, M. (2013). Introduction of the Politics The Devloping World Politics Challeges. Cengage Learning, 342.

8. Mahmood, M. (2006). The Political System of Islamic Republic of Iran. New Dehli: Gyan Publisher.

9. Maloney, S. (2011). The Revolutionary Economy. Washiton: http://iranprimer.usip.org/ resource/revolutionary-economy.

10. Rights, L. C. (2009). The Justice System of Iran. www.hrw.org/world-report-2012/worldreport-2012-iran

11. UNIDO. (2003). Strategy Docoument of Enhance the Contributionof Small and Medum Size Interprizies Secter. United Nation Industrial Devlopment Organization Vienna, 101. 


\title{
Электоральная политика Ирана в XXI веке \\ и ее влияние на развитие страны
}

\author{
Сайед Рахим Аббас ${ }^{a}$ Мухаммад Асим \\ ${ }^{a}$ Колледж Баккара \\ Пакистан \\ ${ }^{\sigma}$ Колледж Асгар Молл, Равалпинди \\ Пакистан
}

\begin{abstract}
После революиии 1979 года политическая система Ирана была трансформирована в президентский тип управления в рамках теократической структуры. Этот опыт был абсолютно новым для населения Ирана после правления династии Пехлеви. Тем не менее данная система показала себя как удачный тип правления, обеспечивший развитие страны. В данной статье представлен обзор основных принципов электоральной политики Ирана u, в частности, результаты президентских выборов ХХІ века. Рассмотрены политики, озвученные президентами, а также влияние реализации данных политик на развитие страны.
\end{abstract}

Ключевые слова: Пехлеви, Хатами, Ахмед Низад, SАT, Хаменеи.

Научная специальность: 23.00.00 - политология. 